\title{
Circulatory and Adipose Tissue Leptin and Adiponectin in Relationship to Resting Energy Expenditure in Patients With Chronic Obstructive Pulmonary Disease
}

\author{
M. BRÚSIK ${ }^{1}$, J. UKROPEC ${ }^{2}$, P. JOPPA ${ }^{1}$, B. UKROPCOVÁ ${ }^{2}$, P. SKYBA ${ }^{1}$, M. BALÁŽ ${ }^{2}$, \\ P. POBEHA ${ }^{1}$, T. KURDIOVÁ ${ }^{2}$, I. KLIMEŠ ${ }^{2}$, I. TKÁČ ${ }^{1}$, D. GAŠPERÍKOVÁ \\ R. TKÁČOVÁ ${ }^{1}$
}

${ }^{1}$ Department of Respiratory Medicine, Faculty of Medicine, P. J. Šafárik University and L. Pasteur University Hospital, Košice, Slovakia, ${ }^{2}$ Institute of Experimental Endocrinology, Slovak Academy of Sciences, Bratislava, Slovakia

Received December 16, 2011

Accepted June 8, 2012

On-line August 8, 2012

\section{Summary}

Increases in resting energy expenditure (REE) likely contribute to weight loss in various chronic diseases. In chronic obstructive pulmonary disease (COPD), relationships between the ventilatory impairment and increased REE, and between disturbances in adipokines and weight loss were previously described. Therefore, we investigated serum levels and adipose tissue expression of leptin and adiponectin, and their relationships to REE in patients with COPD. In 44 patients with stable COPD (38 male; age $62.3 \pm 7.2$ years), REE was assessed using indirect calorimetry. Subcutaneous adipose tissue samples were analyzed using realtime PCR. From underweight $[n=9$; body mass index (BMI) $<20.0 \mathrm{~kg} \cdot \mathrm{m}^{-2}$ ], to normal weight-overweight $(\mathrm{n}=24, \mathrm{BMI}=20.0-$ $\left.29.9 \mathrm{~kg} \cdot \mathrm{m}^{-2}\right)$ and obese patients $\left(n=11 ; B M I \geq 30 \mathrm{~kg} \cdot \mathrm{m}^{-2}\right)$, REE adjusted for body weight decreased (32.9 \pm 6.1 vs. $26.2 \pm 5.8$ vs. $23.9 \pm 6.6$ kcal. $\left.\mathrm{kg}^{-1} .24 \mathrm{~h}^{-1}, \mathrm{p}=0.006\right)$, serum levels and adipose tissue expression of leptin increased ( $p<0.001$ for both), and serum and adipose tissue adiponectin decreased $(p<0.001$; $p=0.004$, respectively). REE was inversely related to serum and adipose tissue leptin ( $R=-0.547, p<0.001 ; R=-0.458, p=0.002)$, and directly to serum adiponectin ( $R=0.316, p=0.039)$. Underweight patients had increased REE compared to normal weight-overweight patients, in association with reductions in serum and adipose tissue leptin, and increased serum adiponectin, suggesting a role of adipokines in energy imbalance in COPD-related cachexia.

\section{Key words}

Chronic obstructive pulmonary disease - Resting energy expenditure $\bullet$ Leptin • Adiponectin • Adipose tissue

\section{Corresponding author}

Ružena Tkáčová, Department of Respiratory Medicine, Faculty of Medicine, P. J. Šafárik University and L. Pasteur University Hospital, Rastislavova 43, Košice, 041 90, Slovakia. Fax: (421) 55 615-2664. E-mail: ruzena.tkacova@upjs.sk

\section{Introduction}

Mechanisms responsible for unintentional weight loss in patients with chronic obstructive pulmonary disease (COPD) are poorly understood. Several pathological processes potentially linked to COPD-related wasting were proposed such as energy imbalance resulting from increased energy expenditure and nutritional insufficiency, systemic inflammation coupled with oxidative stress, disuse muscular atrophy, anabolic hormone insufficiency, sympathetic activation, and tissue hypoxia (Wagner 2008, Raguso and Luthy 2011). Nevertheless, despite reduced quality of life and shortened survival time in underweight patients with COPD (Landbo et al. 1999, Vestbo et al. 2006), studies directly assessing pathological mechanisms potentially involved in COPD-related weight loss are scarce.

Similarly to cancer cachexia (Fouladiun et al. 
2005), significant loss of the both, fat-free mass and body fat occurs in underweight patients with advanced COPD (Engelen et al. 1999, Liu et al. 2009). Animal studies in rodents revealed that fat tissue wasting in cachexia is associated with morphological heterogeneity and shrinking of adipocytes accompanied by increased fibrosis in white adipose tissue (WAT) (Bing et al. 2006). In addition, extensive delipidation in adipocytes was also observed under cachectic conditions (Murphy et al. 2010).

In the last decade the endocrine and secretory function of WAT has been increasingly recognized, and the role of numerous fat cell-derived proteins in the control of various physiological functions has been uncovered. Importantly, adipokines such as leptin are involved also in the control of energy balance (Trayhurn and Bing 2006). Reductions of circulatory leptin levels were reported not only in cancer cachexia (Smiechowska et al. 2010) but also in emphysematous or malnourished patients with COPD (Schols et al. 1999, Yang et al. 2006). In contrast, elevated circulatory adiponectin levels were associated with muscle wasting in cancer cachexia (Wolf et al. 2006). Nevertheless, although leptin appeared to increase energy expenditure in mice (Hamann and Matthaei 1996), the effects of leptin on resting energy expenditure (REE) in humans remain poorly understood (Deemer et al. 2010). While several studies demonstrated associations between circulatory leptin and REE (Jørgensen et al. 1998, Magni et al. 2005), other investigations have found no such relationships (Neuhäuser-Berthold et al. 2000, Usui et al. 2007, Deemer et al. 2010).

REE is the major component of total daily energy expenditure in individuals with limited physical activities. Previously, increases in REE were observed in diseased states associated with cachexia other than COPD (Fredrix et al. 1991). In addition, elevated REE was observed in patients with COPD (Schols et al. 1991a, Creutzberg et al. 1998, Sergi et al. 2006), with the highest values of REE among weight-losing patients (Schols et al. 1991a, Schols et al. 1991b).

In patients with COPD, previous findings demonstrated relationships between the severity of ventilatory impairment and increased REE on one hand (Donahoe et al. 1989), and between disturbances in circulatory adipokine levels and weight loss on the other (Tomoda et al. 2007, Yang et al. 2006). Therefore, a question arose regarding the role of adipose tissue and adipokines in REE in such patients. In the present study, we investigated serum levels and adipose tissue expression of leptin and adiponectin, and their relationships to REE in patients with COPD.

\section{Patients and Methods}

\section{Subjects}

Patients with diagnosis of COPD according to the Global Strategy for Chronic Obstructive Lung Disease (GOLD) recommendations (NHLBI/WHO 2010), free from exacerbation for $\geq 8$ weeks, were recruited from two out-patient clinics affiliated with the university hospital setting. Exclusion criteria were respiratory disorders other than COPD, known metabolic, endocrine, autoimmune, hepatic or renal disorders, malignancy, heart failure, blood coagulation disorders or therapy with warfarin, use of systemic corticosteroids and long-term home oxygen therapy. Dyspnoea severity was evaluated using the Modified Medical Research Council (MMRC) scale. Exercise capacity was assessed using 6-minute walking distance (6MWD). The distance travelled within 6 minutes was recorded without use of supplemental oxygen.

Information regarding COPD exacerbations in the preceding year and medication use was retrieved from patients' charts of the referring physicians. The study was a part of an ongoing study on the metabolic consequences of COPD (MOPD) and had approval of the Ethics Committee of the L. Pasteur University Hospital, Kosice, Slovakia. All subjects gave written consent to the study.

\section{Pulmonary function tests}

Pulmonary function tests, including spirometry and single-breath diffusing capacity for carbon monoxide $\left(\mathrm{DL}_{\mathrm{CO}}\right)$, were assessed with the use of bodyplethysmography (Ganshorn, Germany) in accordance with European Respiratory Society standards (Miller et al. 2005). Tests were performed with patients in a sitting position by the same technician in order to ensure consistency of the technique. Three technically acceptable measurements were performed in each patient, and the highest value was included in the analyses. COPD diagnosis and severity was evaluated on the basis of the GOLD recommendations (NHLBI/WHO 2010).

\section{Body composition}

Body composition was assessed by Dual Energy X-Ray Absorptiometry (DEXA) with fan-beam technology using a total body scanner (Lunar Prodigy, 
GE Healthcare, United Kingdom). Calibration was performed routinely every morning using the standard provided by the manufacturer. Coefficient of variation during measurement of standard phantom was less than $1 \%$. Body weight and fat free mass (FFM) were adjusted for height squared to calculate body mass index (BMI) and fat free mass index (FFMI). Patients with $\mathrm{BMI}<20.0$ kg. $\mathrm{m}^{-2}$ were considered underweight (Landbo et al. 1999, Tomoda et al. 2007). Patients with COPD and BMI $\geq 30.0$ kg. $\mathrm{m}^{-2}$ were diagnosed as obese (Landbo et al. 1999, Vestbo et al. 2006).

\section{Biochemical analyses}

In all patients, peripheral venous blood samples from the antecubital vein were collected between 7.00 and 8.00 a.m. after 10 hour fast. Routine biochemical and hematological assessments were performed at the day of collection. High-sensitivity serum C-reactive protein (hsCRP) levels were assessed by immunoturbidimetric method (Randox, United Kingdom). The analytical sensitivity of this CRP assay is of $0.1 \mathrm{mg} . \mathrm{l}^{-1}$. Serum tumor-necrosis factor (TNF)- $\alpha$ and interleukin (IL)-6 levels were measured using commercially available enzyme-linked immunosorbent assay kits (BeckmannCoulter Immunotech, Germany). At the time of venous blood samples collection, arterial blood sample was obtained by puncture of radial artery to determine arterial carbon dioxide tension $\left(\mathrm{PaCO}_{2}\right)$ and arterial oxygen tension $\left(\mathrm{PaO}_{2}\right)$. Serum leptin and adiponectin were determined by the enzyme-linked immunosorbent assays (DRG, Germany).

\section{Measurements of resting energy expenditure}

Resting energy expenditure (REE) was measured by open-circuit indirect calorimetry using a ventilated hood system (ZAN, Germany). The system was calibrated daily. Prior to each metabolic test, the flowmeter was calibrated using a 3 liter calibration syringe (Pulmonary Data Services Inc., USA) and the gas analyzers were calibrated using a two-point calibration method with certified gases $\left(15.9 \% \mathrm{O}_{2}, 5.0 \% \mathrm{CO}_{2}\right.$, Linde Gas, Slovakia). Patients were examined after at least 10 hours fast, and refraining from smoking, alcohol and caffeine consumption, and vigorous physical activity for 24 hours prior to the test. Patients were placed in a comfortable reclined position, allowed to rest at least $30 \mathrm{~min}$ prior to measurement. The measurements were recorded within a $30 \mathrm{~min}$ period between 8.00 and 9.00 a.m., and REE was calculated from oxygen consumption and carbon dioxide production using the abbreviated Weir equation (Weir 1949). Since the absolute values of REE depend on body size, we calculated the ratio of REE to body weight (REE/BW) as previously described (Schols et al. 1991b, Sergi et al. 2006).

\section{Leptin and adiponectin expression in adipose tissue}

Abdominal subcutaneous adipose tissue was taken by aspiration with a bioptic needle (Medin, Czech Republic) under local intracutaneous anesthesia with $1 \%$ mesocain after an overnight fast between 9.00 and 10.00 a.m. The samples were quickly washed in saline to eliminate blood and other connective tissue, immediately frozen in liquid nitrogen and stored at $-80{ }^{\circ} \mathrm{C}$ until analysis. Total RNA was isolated using the RNeasy® Lipid Tissue mini kit (Qiagen, Germany), DNAse treatment was included. RNA quantity, purity and integrity were determined with the microfluidic chips Experion $^{\mathrm{TM}}$ RNA analysis kit (BioRad, USA) as well as with nanophotometer ${ }^{\mathrm{TM}}$ (IMPLEN, Germany). Reverse transcription was performed with aid of High Capacity RNA to cDNA kit (Applied Biosystems, USA). Gene expression was measured in duplicates with aid of the real-time PCR (RotorGene 2000 real-time cycler, Corbett Research, Australia) using the TaqMan ${ }^{\circledR G}$ Gene Expression Assays for leptin (Hs00174877_m1) and adiponectin (Hs00605917_m1, Applied Biosystems, USA). Comparative quantification method $(\Delta \Delta \mathrm{Ct})$ was used to calculate the relative gene expression (Klein 2002).

\section{Statistical analyses}

Statistical analyses were performed using SPSS software version 14.0 (SPSS Inc., USA). The Kolmogorov-Smirnov test of normality was applied. Differences between groups in normally distributed variables were tested by one-way analysis of variance (ANOVA) with post hoc testing by all pair-wise multiple comparison procedures using the Tukey test. In nonnormally distributed variables, the differences between groups were analysed by ANOVA on ranks using Kruskal-Wallis method and Dunn's method was used for post hoc multiple comparisons. Chi-square test was used to compare the proportion of categorical variables between groups.

Because the distributions of serum hsCRP, TNF$\alpha$ and IL- 6 levels, and of serum leptin and adiponectin concentrations were all skewed, we used the log transformed values of these variables in regression 
Table 1. Patient characteristics.

\begin{tabular}{lccccc}
\hline & & \multicolumn{3}{c}{ Group } \\
\cline { 3 - 4 } Variable & Entire cohort & Underweight & $\begin{array}{c}\text { Normal weight- } \\
\text { overweight }\end{array}$ & Obese & p value \\
\hline Patients, no (\%) & 44 & $9(20.5)$ & $24(54.5)$ & $11(25)$ & \\
Age, years & $62.3 \pm 7.2$ & $61.4 \pm 8.2$ & $63.4 \pm 6.4$ & $60.2 \pm 8.0$ & 0.527 \\
Males, no (\%) & $38(86.3)$ & $9(100)$ & $20(83.3)$ & $9(81.8)$ & 0.406 \\
Current smokers/ & $19(43.2)$ & $5(55.6)$ & $10(41.7)$ & $4(36.4)$ & 0.673 \\
exsmokers, no (\%) & $34.0 \pm 25.1$ & $40.0 \pm 15.0$ & $38.1 \pm 29.4$ & $19.2 \pm 15.4$ & 0.097 \\
Packyears, years & $1.62 \pm 0.82$ & $2.00 \pm 0.71$ & $1.46 \pm 0.93$ & $1.64 \pm 0.50$ & 0.312 \\
MMRC dyspnea scale & $359.5 \pm 90.5$ & $287.7 \pm 84.7^{*}$ & $383.9 \pm 80.9$ & $365.2 \pm 91.3$ & 0.020 \\
6MWD, $m$ & $26.5 \pm 7.1$ & $18.2 \pm 0.8^{* \dagger}$ & $25.2 \pm 2.9$ & $36.0 \pm 5.6^{*}$ & $<0.001$ \\
BMI, kg. m $^{-2}$ & $51.8 \pm 7.1$ & $46.5 \pm 3.4^{\dagger}$ & $51.0 \pm 6.3$ & $57.8 \pm 7.0^{*}$ & $<0.001$ \\
FFM, kg & $18.3 \pm 2.5$ & $16.1 \pm 0.8^{* \dagger}$ & $17.8 \pm 1.5$ & $21.2 \pm 2.6^{*}$ & $<0.001$ \\
FFMI, kg.m ${ }^{-2}$ & $27.6 \pm 12.9$ & $10.6 \pm 6.7^{* \dagger}$ & $27.9 \pm 8.6$ & $40.6 \pm 6.7^{*}$ & $<0.001$ \\
Fat percentage, \% & $22.9 \pm 13.9$ & $6.3 \pm 4.2^{* \dagger}$ & $21.1 \pm 7.5$ & $40.0 \pm 10.1^{*}$ & $<0.001$ \\
Fat mass, kg & & & &
\end{tabular}

$* p<0.05$ versus normal weight-overweight group. $+p<0.05$ versus obese group. Values are given as the mean \pm SD. MMRC - The Modified Medical Research Council Dyspnea Scale; 6MWD - 6 minutes walking distance; BMI - body mass index; FFM - fat free mass; FFMI - fat free mass index.

analyses. Least-squares linear regression analysis was used to assess the unadjusted relationships between the REE and serum parameters, and between REE and adipose tissue expression. Pearson product-moment correlation coefficient $(\mathrm{R})$ is reported to show the degree of linear relationship between variables.

In the multivariate analyses, multiple linear regression models were used with REE per $\mathrm{kg}$ of body weight as the dependent variable, and age, gender, forced expiratory volume in 1 second $\left(\mathrm{FEV}_{1}\right)$ to forced vital capacity (FVC) ratio, fat mass, and either log transformed serum leptin, leptin adipose tissue expression, or log transformed serum adiponectin levels as independent variables. Coefficient of determination $\left(R^{2}\right)$ is reported to indicate the model fit, and percentage of variance of the dependent variables explained by the predictors included in the model. Because of an existing co-linearity between leptin adipose tissue expression and fat mass, we calculated a multiple linear regression model without, and with fat mass included as an independent variable.

A $p$ value of $<0.05$ was considered statistically significant. Continuous variables with normal distribution are shown as means $\pm \mathrm{SD}$, non-normally distributed variables as median (interquartile range).

\section{Results}

Patients

We recruited 44 patients (38 men and 6 women) with stable COPD. They were generally late middle-aged (mean age $62.3 \pm 7.2$ years) with a mean $34.0 \pm 25.1$ packyears history of smoking.

Patients were divided into three groups according to BMI: the first was formed by nine underweight patients $\left(\mathrm{BMI}<20.0 \mathrm{~kg} \cdot \mathrm{m}^{-2}\right)$, the second by 24 normal weight-overweight (BMI 20.0-29.9 $\mathrm{kg} \cdot \mathrm{m}^{-2}$ ), and the third by 11 obese patients $\left(B M I \geq 30 \mathrm{~kg} \cdot \mathrm{m}^{-2}\right.$ ).

Table 1 displays demographic data and body composition parameters in the three groups. No differences were observed between the groups in the mean age, proportion of females, smoking history or MMRC dyspnea score. Underweight patients performed significantly lower on the 6 minutes-walking distance test than normal weight-overweight individuals $(\mathrm{p}<0.05)$.

From underweight to normal weight-overweight and obese group, FFM, FFMI, fat mass, and fat percentage increased ( $p$ for trend $<0.001$ for all) (Table 1). Underweight patients had significantly lower FFMI, fat mass and fat percentage compared to normal weight-overweight individuals ( $\mathrm{p}<0.05$ for all). 
Table 2. Pulmonary functions and arterial blood gases.

\begin{tabular}{|c|c|c|c|c|c|}
\hline \multirow[b]{2}{*}{ Variable } & \multirow[b]{2}{*}{ Entire cohort } & \multicolumn{3}{|c|}{ Group } & \multirow[b]{2}{*}{$p$ value } \\
\hline & & Underweight & $\begin{array}{c}\text { Normal weight- } \\
\text { overweight }\end{array}$ & Obese & \\
\hline$F E V_{l}, l$ & $1.64 \pm 0.75$ & $1.13 \pm 0.85$ & $1.78 \pm 0.71$ & $1.74 \pm 0.62$ & 0.069 \\
\hline$F E V_{1}, \%$ pred & $54.0 \pm 23.3$ & $33.8 \pm 19.8^{* \dagger}$ & $59.4 \pm 22.7$ & $60.5 \pm 19.0$ & 0.020 \\
\hline$F V C, l$ & $3.1 \pm 0.8$ & $2.8 \pm 1.1$ & $3.3 \pm 0.6$ & $2.9 \pm 0.8$ & 0.189 \\
\hline$F V C, \%$ pred & $83.1 \pm 16.9$ & $68.1 \pm 19.6^{*}$ & $89.2 \pm 12.1$ & $82.0 \pm 17.3$ & 0.004 \\
\hline$F E V_{1} / F V C$ ratio & $50.9 \pm 16.9$ & $38.7 \pm 15.2^{\dagger}$ & $51.9 \pm 17.0$ & $58.6 \pm 13.2$ & 0.025 \\
\hline$R V, l$ & $4.12 \pm 1.39$ & $5.26 \pm 1.44 *^{\dagger}$ & $4.01 \pm 1.29$ & $3.42 \pm 1.04$ & 0.008 \\
\hline$R V, \%$ pred & $176.3 \pm 53.2$ & $221.0 \pm 59.4^{* \dagger}$ & $169.8 \pm 47.2$ & $154.1 \pm 42.3$ & 0.010 \\
\hline$T L C, l$ & $7.28 \pm 1.52$ & $8.14 \pm 1.06^{\dagger}$ & $7.34 \pm 1.59$ & $6.45 \pm 1.32$ & 0.040 \\
\hline$T L C, \%$ pred & $113.5 \pm 17.5$ & $121.2 \pm 18.2$ & $114.5 \pm 17.8$ & $105.1 \pm 13.8$ & 0.110 \\
\hline$R V / T L C$ ratio & $55.6 \pm 10.5$ & $64.3 \pm 13.7^{* \dagger}$ & $53.7 \pm 7.9$ & $52.5 \pm 9.5$ & 0.015 \\
\hline$D L_{C O}, \%$ pred & $72.3 \pm 30.9$ & $34.2 \pm 24.3 *^{\dagger}$ & $76.3 \pm 28.7$ & $92.0 \pm 7.6$ & 0.002 \\
\hline $\mathrm{PaO}_{2}, \mathrm{kPa}$ & $9.17 \pm 1.82$ & $7.83 \pm 2.60 *$ & $9.67 \pm 1.57$ & $9.19 \pm 1.00$ & 0.032 \\
\hline $\mathrm{PaCO}_{2}, \mathrm{kPa}$ & $5.08 \pm 0.88$ & $5.31 \pm 1.06$ & $4.94 \pm 0.77$ & $5.18 \pm 0.96$ & 0.687 \\
\hline
\end{tabular}

$* \mathrm{p}<0.05$ versus normal weight-overweight group. $+\mathrm{p}<0.05$ versus obese group. Values are given as the mean \pm SD. $\%$ pred percentage of predicted value; $\mathrm{FEV}_{1}$ - forced expiratory volume in 1 second; FVC - forced vital capacity; RV - residual volume; TLC total lung capacity; $\mathrm{DL}_{\mathrm{CO}}$ - diffuse capacity for carbon monoxide; $\mathrm{PaO}_{2}$ - partial pressure of oxygen; $\mathrm{PaCO} \mathrm{C}_{2}$ - partial pressure of carbon dioxide.

With increases in BMI, $\mathrm{FEV}_{1}, \mathrm{FVC}, \mathrm{FEV}_{1} / \mathrm{FVC}$ ratio, lung diffusion capacity and $\mathrm{PaO}_{2}$ significantly increased, whereas residual volume (RV) and RV/total lung capacity (TLC) ratio significantly decreased (Table 2). Underweight patients had significantly more profound obstructive ventilatory impairment (reflected by lower $\mathrm{FEV}_{1}$ ), pulmonary hyperinflation (reflected by increases in RV and RV/TLC ratio), and lower lung diffusion capacity compared to normal weightoverweight individuals ( $\mathrm{p}<0.05$ for all comparisons). In addition, 6MWD correlated directly with $\mathrm{FEV}_{1}$ and $\mathrm{FVC}$ $(\mathrm{R}=0.484, \mathrm{p}<0.001 ; \mathrm{R}=0.450, \mathrm{p}<0.002$, respectively), and inversely with $\mathrm{RV} / \mathrm{TLC}(\mathrm{R}=-0.481, \mathrm{p}<0.001)$.

\section{Resting energy expenditure}

From underweight to normal weight-overweight and obese patients, REE/BW significantly decreased (from $32.9 \pm 6.1$ to $26.2 \pm 5.8$ to $23.9 \pm 6.6 \quad \mathrm{kcal} \cdot \mathrm{kg}^{-1} .24 \mathrm{~h}^{-1}$, $\mathrm{p}=0.006$ ) (Fig. 1). In post-hoc analyses, underweight patients had significantly higher REE/BW compared to normal weight-overweight individuals $(\mathrm{p}<0.05)$. REE/BW correlated inversely with BMI, total fat percentage and fat mass $(\mathrm{R}=-0.469, \mathrm{p}=0.001 ; \mathrm{R}=-0.484, \mathrm{p}=0.002 ; \mathrm{R}=-0.538$, $\mathrm{p}<0.001$, respectively). In addition, $\mathrm{REE} / \mathrm{BW}$ correlated inversely with $\mathrm{FEV}_{1}$ and $\mathrm{FEV}_{1} / \mathrm{FVC}$ ratio $(\mathrm{R}=-0.365$, $p=0.015 ; R=-0.317, p=0.036$, respectively). Nevertheless,

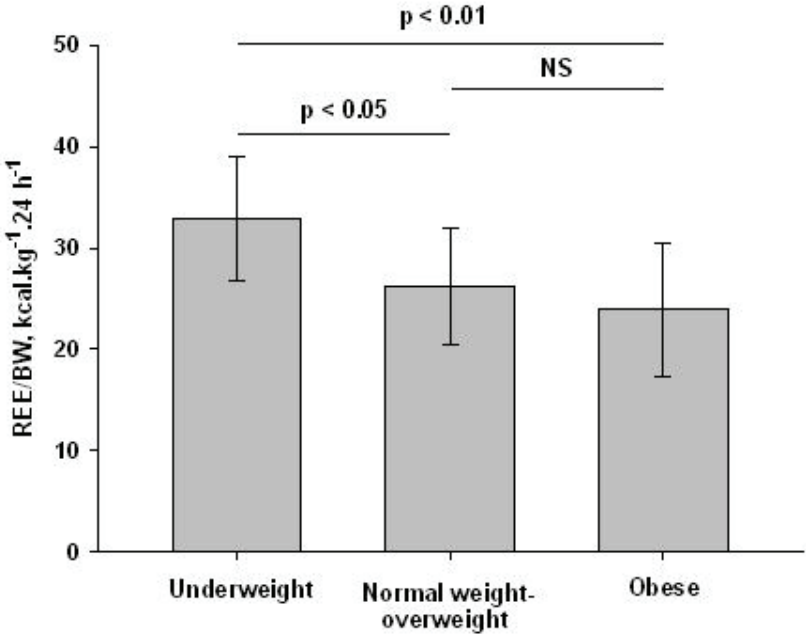

Fig. 1. Comparison of resting energy expenditure per $\mathrm{kg}$ of body weight (REE/BW) in patients with COPD (ANOVA, $P$ for trend 0.006).

no relationships between REE/BW and 6MWD was observed $(\mathrm{R}=-0.0106, \mathrm{p}=0.946)$.

Serum markers of inflammation and serum adipokine levels

No differences were observed between the three groups in circulatory leukocytes or neutrophil counts, nor in serum hsCRP, IL-6 and TNF- $\alpha$ levels (Table 3). From 
Table 3. Serum parameters of inflammation and serum adipokines levels.

\begin{tabular}{|c|c|c|c|c|c|}
\hline \multirow[b]{2}{*}{ Variable } & \multirow[b]{2}{*}{ Entire cohort } & \multicolumn{3}{|c|}{ Group } & \multirow[b]{2}{*}{$p$ value } \\
\hline & & Underweight & $\begin{array}{c}\text { Normal weight- } \\
\text { overweight }\end{array}$ & Obese & \\
\hline Leukocytes, $x 10^{9} . l^{-1}$ & $\begin{array}{c}7.00 \\
(5.6-8.2)\end{array}$ & $\begin{array}{c}6.1 \\
(5.5-8.0)\end{array}$ & $\begin{array}{c}7.1 \\
(6.3-8.2)\end{array}$ & $\begin{array}{c}7.0 \\
(5.7-8.8)\end{array}$ & 0.986 \\
\hline Neutrophils, $x 10^{9} . l^{-1}$ & $\begin{array}{c}4.1 \\
(3.3-4.6)\end{array}$ & $\begin{array}{c}3.3 \\
(3.2-4.9)\end{array}$ & $\begin{array}{c}4.2 \\
(3.5-4.7)\end{array}$ & $\begin{array}{c}4.1 \\
(3.3-4.6)\end{array}$ & 0.705 \\
\hline$h s C R P, m g \cdot m l^{-1}$ & $\begin{array}{c}3.10 \\
(1.03-7.75)\end{array}$ & $\begin{array}{c}3.45 \\
(0.76-7.35)\end{array}$ & $\begin{array}{c}2.00 \\
(1.05-9.75)\end{array}$ & $\begin{array}{c}3.60 \\
(1.18-4.60)\end{array}$ & 0.920 \\
\hline$I L-6, p g \cdot m l^{-1}$ & $\begin{array}{c}3.70 \\
(2.90-5.50)\end{array}$ & $\begin{array}{c}4.30 \\
(3.15-5.15)\end{array}$ & $\begin{array}{c}3.50 \\
(2.10-5.43)\end{array}$ & $\begin{array}{c}4.40 \\
(3.00-8.58)\end{array}$ & 0.385 \\
\hline$T N F-\alpha, p g \cdot m l^{-1}$ & $\begin{array}{c}13.40 \\
(10.63-17.50)\end{array}$ & $\begin{array}{c}9.75 \\
(8.60-14.05)\end{array}$ & $\begin{array}{c}13.35 \\
(11.00-19.40)\end{array}$ & $\begin{array}{c}15.20 \\
(11.33-17.28)\end{array}$ & 0.127 \\
\hline Leptin, $n g . m l^{-1}$ & $\begin{array}{c}6.20 \\
(2.05-19.50)\end{array}$ & $\begin{array}{c}0.60 \\
(0.00-1.60)^{* \dagger}\end{array}$ & $\begin{array}{c}5.45 \\
(2.25-11.65)\end{array}$ & $\begin{array}{c}22.60 \\
(13.58-43.38)^{*}\end{array}$ & $<0.001$ \\
\hline Adiponectin, $\mu g . m l^{-1}$ & $\begin{array}{c}13.9 \\
(8.9-20.5)\end{array}$ & $\begin{array}{c}24.8 \\
(18.0-30.8)^{* \dagger}\end{array}$ & $\begin{array}{c}14.0 \\
(9.2-16.8)\end{array}$ & $\begin{array}{c}9.0 \\
(5.9-11.0)\end{array}$ & $<0.001$ \\
\hline
\end{tabular}

$* p<0.05$ versus normal weight-overweight group. $+p<0.05$ versus obese group. Values are given as median (interquartile range). IL-6 - interleukin 6; TNF-a - tumor necrosis factor-alpha; hsCRP - high sensitivity C-reactive protein.

Table 4. Adipose tissue relative expression of leptin and adiponectin in COPD patients.

\begin{tabular}{|c|c|c|c|c|c|}
\hline \multirow{2}{*}{$\begin{array}{l}\text { mRNA } \\
\text { expression } \\
(\Delta \Delta \mathbf{C t})\end{array}$} & \multirow[b]{2}{*}{ Entire cohort } & \multicolumn{3}{|c|}{ Group } & \multirow[b]{2}{*}{$p$ value } \\
\hline & & Underweight & $\begin{array}{c}\text { Normal weight- } \\
\text { overweight }\end{array}$ & Obese & \\
\hline Leptin & $39.9 \pm 24.6$ & $8.8 \pm 9.4^{*^{\dagger}}$ & $44.1 \pm 20.9$ & $58.1 \pm 15.8$ & $<0.001$ \\
\hline Adiponectin & $184.2 \pm 87.4$ & $201.6 \pm 100.7^{\dagger}$ & $209.4 \pm 79.2$ & $107.9 \pm 46.2 *$ & 0.004 \\
\hline
\end{tabular}

$* p<0.05$ versus normal weight-overweight group. $+p<0.05$ versus obese group. Values are given as the mean \pm SD.

underweight to normal weight-overweight and obese patients, serum leptin levels significantly increased $(\mathrm{p}<0.001)$, whereas adiponectin levels decreased $(p<0.001)$. Underweight patients had significantly lower serum leptin and higher serum adiponectin levels compared to normal weight-overweight individuals ( $p<0.05$ for both). Significant relationships were observed between log transformed serum leptin and adiponectin and $\mathrm{FEV}_{1}(\mathrm{R}=0.481, \mathrm{p}=0.001 ; \mathrm{R}=-0.324, \mathrm{p}=0.034$, respectively). In contrast, no significant relationships were observed between serum adipokines levels, 6MWD and circulatory concentrations of inflammatory markers hsCRP, IL-6 and TNF- $\alpha$ (data not shown).

\section{Adipose tissue expression of leptin and adiponectin}

From underweight to normal weight-overweight and obese patients, adipose tissue mRNA expression of leptin significantly increased, whereas adiponectin expression decreased $(\mathrm{p}<0.001 ; \mathrm{p}=0.004$, respectively) (Table 4). Underweight patients had significantly lower adipose tissue leptin expression compared to normal weight-overweight subjects $(\mathrm{p}<0.05)$.

Adipose tissue leptin mRNA expression correlated directly with fat percentage and fat mass ( $\mathrm{R}=0.896, \mathrm{p}<0.001 ; \mathrm{R}=0.807, \mathrm{p}<0.001$, respectively). In contrast, adiponectin expression correlated inversely with fat percentage and fat mass $(\mathrm{R}=-0.392, \mathrm{p}=0.016$; $\mathrm{R}=-0.406, \mathrm{p}=0.008$, respectively). In addition, adipose tissue leptin expression was related directly to $\mathrm{FEV}_{1}$ and $\mathrm{FEV}_{1} / \mathrm{FVC}$ ratio, and inversely to $\mathrm{RV}(\mathrm{R}=0.440, \mathrm{p}=0.003$; $\mathrm{R}=0.450, \mathrm{p}=0.002 ; \mathrm{R}=-0.492, \mathrm{p}<0.001$, respectively). Nevertheless, no relationships were observed between adipose tissue leptin or adiponectin and 6MWD, or between adipose tissue adiponectin and lung functions. 

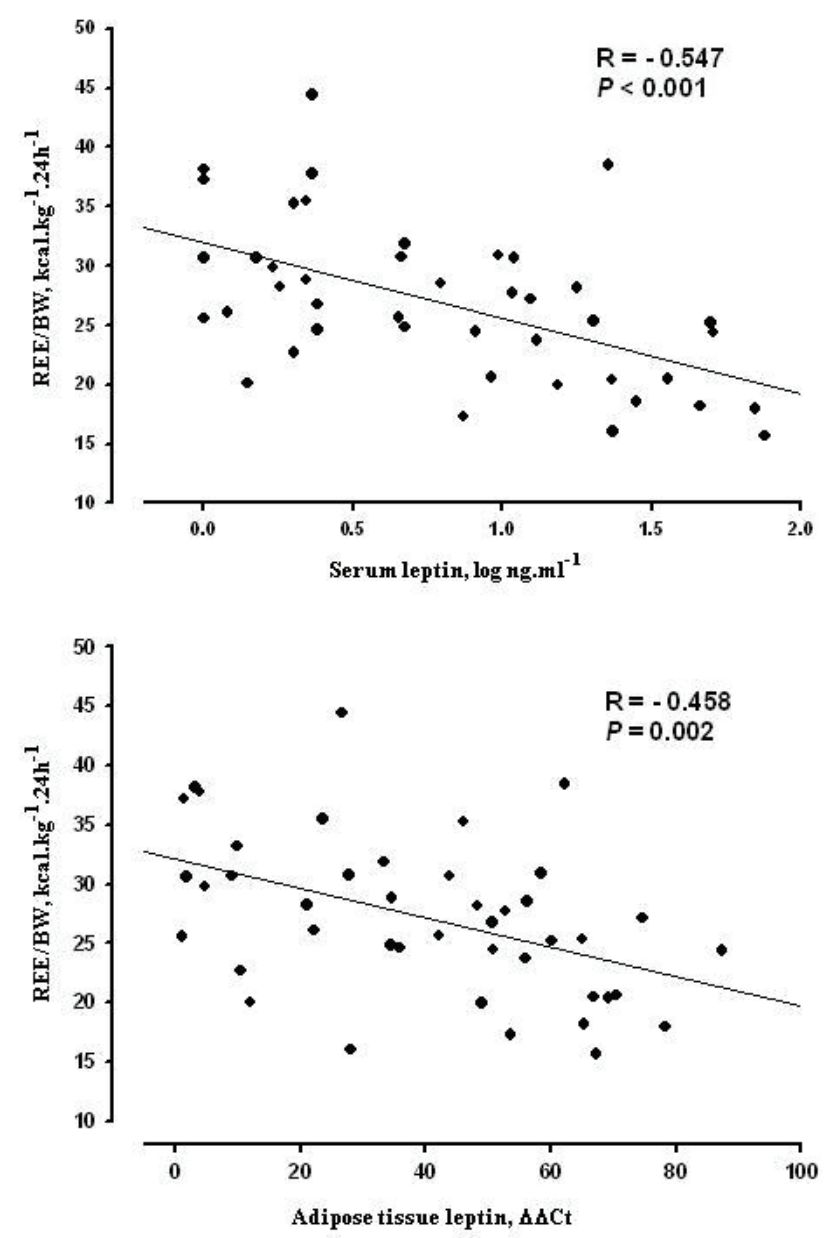

Fig. 2. Relationships between serum and adipose tissue leptin and resting energy expenditure per $\mathrm{kg}$ of body weight (REE/BW) in patients with COPD.

\section{Adipokines and resting energy expenditure}

In the entire cohort, resting energy expenditure was related inversely to $\log$ serum leptin and adipose tissue leptin expression $(\mathrm{R}=-0.547, \mathrm{p}<0.001 ; \mathrm{R}=-0.458$, $\mathrm{p}=0.002$ ) (Fig. 2). In addition, resting energy expenditure was related directly to $\log$ serum adiponectin levels, whereas no significant relationship was observed between subcutaneous adipose tissue adiponectin expression and $\mathrm{REE} / \mathrm{BW} \quad(\mathrm{R}=0.316, \quad \mathrm{p}=0.039 ; \quad \mathrm{R}=0.149, \quad \mathrm{p}=0.339$, respectively).

In multiple linear regression analysis with $\mathrm{REE} / \mathrm{BW}$ as the dependent variable and age, gender, $\mathrm{FEV}_{1} / \mathrm{FVC}$ ratio, and serum leptin as independent variables, only serum leptin $\left(\mathrm{p}=0.016, \quad R^{2}=0.336\right)$ independently predicted REE/BW. In an analogical analysis with serum adiponectin as an independent variable, serum adiponectin and gender were the only independent predictors of REE/BW ( $p=0.050, p=0.026$, respectively; $R^{2}=0.298$ ). Moreover, adipose tissue leptin independently predicted REE/BW before fat mass was introduced into the multivariate analysis $(\mathrm{p}=0.043$, $R^{2}=0.274$ ). Nevertheless, when fat mass was introduced into this model as the next independent variable, adipose tissue leptin expression did not retain its independent predictive value, and total fat mass represented the only independent predictor of REE/BW ( $\mathrm{p}=0.026, R^{2}=0.375$ ).

\section{Discussion}

The present study provides a novel observation on the role of adipokines in resting metabolic rate in patients with COPD. Our data demonstrate that underweight patients with COPD have increased resting energy expenditure, in association with reductions in their subcutaneous adipose tissue leptin expression and serum leptin levels, and increased serum adiponectin levels. Previous findings in COPD demonstrated relationships between the degree of ventilatory impairment and increased REE (Donahoe et al. 1989), and disturbances in circulatory adipokines among those COPD patients who were underweight (Yang et al. 2006, Tomoda et al. 2007, Liu et al. 2009). By concomitant assessment of REE, body composition, circulatory leptin and adiponectin levels and their respective expression within the WAT, our findings are the first to suggest that adipokine levels reflect higher metabolic rate and adipose tissue depletion among patients with COPD and low body weight.

Unexplained weight loss commonly occurs in COPD. In such patients, cachexia is a major clinical problem, which is difficult to reverse, has negative prognostic value, and is associated with serious comorbidities (Wagner 2008). The prevalence of weight loss in COPD increases with disease progression. Significant weight loss experiences up to $15 \%$ of patients with mild-to-moderate disease (Landbo et al. 1999), and cachexia occurs in up to $30 \%$ of those with very severe COPD (Vestbo et al. 2006). Weight-losing patients with COPD suffer from both, loss of FFM and the loss of FM. This phenomenon has been first described in 1999 by Engelen et al. who observed different patterns of chronic tissue wasting among COPD patients with different phenotype. While patients with predominant emphysema suffered from the depletion of the both FFM and FM, patients with predominant chronic bronchitis experienced selective loss of FFM. Likewise, a recent report in underweight patients with COPD and mean BMI of $18.4 \mathrm{~kg} . \mathrm{m}^{-2}$ demonstrated both, significant depletion of FFM and FM compared to the control group with normal 
BMI (Liu et al. 2009). Consequently, parallel loss of muscle and fat mass likely occurs at least in some underweight patients with advanced COPD. However, in contrast to increasing number of studies unraveling functional and clinical implications of obesity in COPD (Franssen et al. 2008), the data on the consequences of adipose tissue wasting are scarce.

The pathogenesis of weight loss in COPD is multifactorial, including systemic inflammation associated with cytokine-mediated metabolic derangements, tissue hypoxia and oxidative stress (Agustí et al. 2004), increased work of breathing resulting in increases in REE (Donahoe et al. 1989), disuse muscle atrophy, sympathetic activation, and anabolic hormone insufficiency (Wagner 2008). In such patients, energy imbalance likely results from the both nutritional insufficiency and increased energy expenditure (Schols et al. 1991b, Raguso and Luthy 2011). Indeed, several studies demonstrated increases in REE in patients with COPD (Schols et al. 1991a, Creutzberg et al. 1998, Sergi et al. 2006). In agreement with previous reports, results of the present study suggest that increases in resting energy requirements are most profound among malnourished patients (Donahoe et al. 1989, Schols et al. 1991b). Importantly, Donahoe et al. (1989) were the first to describe an association between increased REE, the degree of emphysema and inspiratory muscle weakness, and suggested that increased energy requirements result from augmenting ventilation and increased mechanical work load associated with severe COPD. Our observations demonstrating the most severe ventilatory impairment among underweight patients who were hypermetabolic complement these findings, and extend them further by exploring associations between energy expenditure and adipokine levels.

Leptin, a hormone secreted by adipose tissue, is an integral component of the homeostatic loop of body weight regulation. Leptin acts to control food intake and energy expenditure via neuropeptidergic effector molecules within the hypothalamus. While leptin increases metabolic rate in ob/ob mice, these effects are less obvious in wild-type animals (Pelleymounter et al. 1995). In addition, human studies on the relationships between serum leptin levels and energy expenditure yielded inconsistent results: some did not reveal any relationship between leptin and REE (NeuhäuserBerthold et al. 2000, Usui et al. 2007, Deemer et al. 2010), while other reported either a positive (Jørgensen et al. 1998) or a negative correlation (Niskanen et al. 1997).
Previous studies in COPD patients did not report significant relationships between circulating leptin levels and REE in normal-weight patients with stable COPD (Cohen et al. 2003, Shin et al. 2007). Some of the inconsistencies observed previously may result from the methodological reasons: since fat mass not only determines serum leptin levels but, besides FFM, also affects REE (Ferraro and Ravussin 1992), analyses of the relationships between leptin and REE require careful adjustments for fat mass (Usui et al. 2007). Indeed, in the present study adipose tissue leptin expression was significantly related to resting metabolic rate before adjustments for fat mass, nevertheless, only fat mass predicted REE in the final model. Similar observations suggesting that leptin per se does not directly influence REE were recently published in senior women (Neuhäuser-Berthold et al. 2000, Usui et al. 2007) and men (Neuhäuser-Berthold et al. 2000). In the present study we have also observed the lowest adipose tissue expression of leptin in those patients who were underweight. Therefore, reductions of circulating leptin levels in COPD-related cachexia likely result not only from the depletion of adipose tissue per se but also from reductions in relative gene expression of leptin within the adipose tissue. Since reductions in leptin levels reflect higher metabolic rate and adipose tissue depletion in underweight patients with COPD, low circulatory leptin concentrations might potentially serve as a biomarker of catabolism in clinical conditions associated with wasting. This hypothesis needs to be addressed by future studies.

Adiponectin is the only adipocytokine with antiinflammatory and antiobesity effects. Previously, increases in circulatory adiponectin were observed in conditions associated with tissue wasting such as anorexia nervosa (Pannacciulli et al. 2003) and cancer cachexia (Wolf et al. 2006). In patients with COPD, Tomoda et al. (2007) observed remarkable elevations of plasma adiponectin in underweight patients, and speculated that elevations of plasma adiponectin levels may be linked to persistent excess respiratory exercise caused by hyperinflation, and may thus contribute to the development of cachexia. Nevertheless, REE was not measured in that study. Our present observations demonstrating an inverse association between adiponectin and BMI extend previous findings (Tomoda et al. 2007, Chan et al. 2010) by demonstrating, for the first time, a direct relationship between energy expenditure and serum adiponectin levels among patients with COPD. Recently, parallel increases in REE and adiponectin were reported 
after resistance exercise in elderly individuals (Fatouros et al. 2009). Nonetheless, the independent predictive value of serum adiponectin on resting energy expenditure in the present study was altered by inclusion of fat mass into the model such that fat mass was the only independent predictor of REE in the final model. Importantly, underweight patients had more severe bronchial obstruction and pulmonary hyperinflation, in association with higher serum adiponectin and REE/BW compared to normal weight-overweight COPD patients. Therefore, it is tempting to hypothesize that chronic excess respiratory exercise due to increased respiratory muscle work load represents one of key pathophysiological mechanisms resulting in concomitant increases in metabolic rate, tissue wasting, and alterations in adipokines in patients with advanced COPD. Studies employing parallel measurements of REE and of respiratory pattern and inspiratory work load using advanced techniques (Dellweg et al. 2008) in COPD patients may shed more light on this question.

Previously, several treatment approaches were tested with the aim to reverse weight loss in patients with COPD including active nutritional support, exercise training and optimizing bronchodilator treatment or oxygen supply (Wagner 2008). Nevertheless, improvements achieved by any of these methods were modest in underweight patients (Wagner 2008). The current lack of highly efficient methods to reverse weight loss in COPD coupled with findings of the present study warrant the need to test various weight loss preventive strategies before the initiation of energy expenditure rise associated with disturbances of adipokines, and before the development of manifest cachexia. Addressing these questions is of vital importance for hypermetabolic patients at risk of nutritional insufficiency and subsequent wasting.

There are several limitations to this study. First, only a limited number of patients was studied. However, compared to patients with $\mathrm{BMI} \geq 20 \mathrm{~kg} \cdot \mathrm{m}^{-2}$, underweight patients with COPD had median values of REE/BW increased by $22 \%$, serum leptin reduced by $94 \%$, and serum adiponectin increased by $131 \%$. Therefore, although our results are robust to gain some understanding on the role of adipokines in COPD-related increases in metabolic rate and weight loss, they should be considered preliminary and hypothesis generating. Second, exploring gender differences in the outcomes of interest was beyond the scope of the present study, and indeed, only six women were recruited. Recently, Breyer et al. (2011) demonstrated a significant interaction between gender and BMI on serum leptin/fat mass ratio. Therefore, we performed further analyses examining the relationships between adipokines and resting energy expenditure in males only $(n=38)$. Results of these analyses were unequivocally similar to those observed in the entire cohort: serum and adipose tissue leptin were related inversely to $\mathrm{REE} / \mathrm{BW} \quad(\mathrm{R}=-0.435, \mathrm{p}=0.007$; $\mathrm{R}=-0.372, \quad \mathrm{p}=0.022$, respectively), while serum adiponectin was related directly to $\mathrm{REE} / \mathrm{BW}(\mathrm{R}=0.395$, $\mathrm{p}=0.016$ ). Measurements of adipokines' expression in samples from subcutaneous depots of adipose tissue only represents the third limitation since the expression of leptin and adiponectin may differ between subcutaneous and visceral adipose tissue. In particular, adiponectin is primarily produced by visceral adipose tissue (Motoshima et al. 2002). Consequently, circulating adiponectin levels more reliably reflect visceral compared to subcutaneous adipose tissue production of adiponectin. Indeed, while we observed a significant relationship between serum adiponectin and REE, no such relationship was observed when adipose tissue adiponectin expression was introduced into the analysis. Final limitation of the study relates to its cross-sectional nature that does not allow for the determination of timecourse relationship between REE, weight loss and adipokines. Nevertheless, concomitant measurements, within one group of patients with COPD, of REE, body composition, and of serum and adipose tissue adipokines are unique and represent strength of the study.

In conclusion, our study highlights the role of adipose tissue and adipokines in energy expenditure in patients with COPD. The observation of alterations in adipokine levels and increased metabolic rate among underweight patients, in association with relationships between leptin and adiponectin and resting metabolic rate in the entire cohort are novel, and suggest that fat metabolism is a factor linked to metabolic rate in patients with COPD. Importantly, the effects of the both, leptin and adiponectin on resting metabolic rate do not appear to be independent of fat mass and, therefore, both hormones likely represent fat-tissue derived mediators of energy expenditure. Further studies are needed to address the pathological mechanisms underlying the observed relationships in more details.

\section{Conflict of Interest}

There is no conflict of interest. 


\section{Acknowledgements}

This work was supported by the Slovak Research and Development Agency under the contract No. APVV0122-06 and APVV-0134-11, and by grants VEGA 1/0227/11 and VEGA 1/0111/12 of the Ministry of Education, Slovakia. The authors wish to express their gratitude to Drs. Maria Pobehova and Stefan Toth who referred patients to the study from their out-patient clinics; to Mrs. Dana Lalkovicova, the head nurse at the
Pulmonary Function Laboratory, and to Mrs. Miroslava Pavuckova, the research nurse who assisted in adipose tissue biopsies at the Department of Respiratory Medicine, Faculty of Medicine and L. Pasteur University Hospital, Kosice, well as to Mrs. Alica Mitkova for the versatile skilful technical assistance in the Diabetes Laboratory, Institute of Experimental Endocrinology Slovak Academy of Sciences, Bratislava, Slovakia.

\section{References}

AGUSTÍ A, MORLÁ M, SAULEDA J, SAUS C, BUSQUETS X: NF-kappaB activation and iNOS upregulation in skeletal muscle of patients with COPD and low body weight. Thorax 59: 483-487, 2004.

BING C, RUSSELL S, BECKET E, POPE M, TISDALE MJ, TRAYHURN P, JENKINS JR: Adipose atrophy in cancer cachexia: morphologic and molecular analysis of adipose tissue in tumour-bearing mice. Br J Cancer 95: 1028-1037, 2006.

BREYER MK, RUTTEN EP, VERNOOY JH, SPRUIT MA, DENTENER MA, VAN DER KALLEN C, VANGREEVENBROEK MM, WOUTERS EF. Gender differences in the adipose secretome system in chronic obstructive pulmonary disease (COPD): a pivotal role of leptin. Respir Med 105: 1046-1053, 2011.

CHAN KH, YEUNG SC, YAO TJ, IP MS, CHEUNG AH, CHAN-YEUNG MM, MAK JC; COPD STUDY GROUP OF THE HONG KONG THORACIC SOCIETY: Elevated plasma adiponectin levels in patients with chronic obstructive pulmonary disease. Int J Tuberc Lung Dis 14: 1193-1200, 2010.

COHEN RI, MARZOUK K, BERKOSKI P, O'DONNELL CP, POLOTSKY VY, SCHARF SM: Body composition and resting energy expenditure in clinically stable, non-weight-losing patients with severe emphysema. Chest 124: 1365-1372, 2003.

CREUTZBERG EC, SCHOLS AM, BOTHMER-QUAEDVLIEG FC, WOUTERS EF: Prevalence of an elevated resting energy expenditure in patients with chronic obstructive pulmonary disease in relation to body composition and lung function. Eur J Clin Nutr 52: 396-401, 1998.

DEEMER SE, KING GA, DORGO S, VELLA CA, TOMAKA JW, THOMPSON DL: Relationship of leptin, resting metabolic rate, and body composition in premenopausal hispanic and non-hispanic white women. Endocrine Res 35: 95-105, 2010.

DELLWEG D, HAIDL P, SIEMON K, APPELHANS P, KOEHLER D: Impact of breathing pattern on work of breathing in healthy subjects and patients with COPD. Respir Physiol Neurobiol 161: 197-200, 2008.

DONAHOE M, ROGERS RM, WILSON DO, PENNOCK BE: Oxygen consumption of the respiratory muscles in normal and in malnourished patients with chronic obstructive pulmonary disease. Am Rev Respir Dis 140: 385 391, 1989.

ENGELEN MP, SCHOLS AM, LAMERS RJ, WOUTERS EF: Different patterns of chronic tissue wasting among patients with chronic obstructive pulmonary disease. Clin Nutr 18: 275-280, 1999.

FATOUROS IG, CHATZINIKOLAOU A, TOURNIS S, NIKOLAIDIS MG, JAMURTAS AZ, DOUROUDOS II, PAPASSOTIRIOU I, THOMAKOS PM, TAXILDARIS K, MASTORAKOS G, MITRAKOU A: Intensity of resistance exercise determines adipokine and resting energy expenditure responses in overweight elderly individuals. Diab Care 32: 2161-2167, 2009.

FERRARO R, RAVUSSIN E: Fat mass in predicting resting metabolic rate. Am J Clin Nutr 56: 460-461, 1992.

FOULADIUN M, KÖRNER U, BOSAEUS I, DANERYD P, HYLTANDER A, LUNDHOLM KG: Body composition and time course changes in regional distribution of fat and lean tissue in unselected cancer patients on palliative care - correlations with food intake, metabolism, exercise capacity, and hormones. Cancer 103: 2189-2198, 2005. 
FRANSSEN FM, O'DONNELL DE, GOOSSENS GH, BLAAK EE, SCHOLS AM: Obesity and the lung: 5. Obesity and COPD. Thorax 63: 1110-1117, 2008.

FREDRIX EWHM, SOETERS PB, WOUTERS EFM, DEERENBERG IM, VON MEYENFELDT MF, SARIS WHM: Effect of different tumor types on resting energy expenditure. Cancer Res 51: 6138-6141, 1991.

HAMANN A, MATTHAEI S: Regulation of energy balance by leptin. Exp Clin Endocrinol Diab 104: 293-300, 1996.

JØRGENSEN JO, VAHL N, DALL R, CHRISTIANSEN JS: Resting metabolic rate in healthy adults: relation to growth hormone status and leptin levels. Metabolism 47: 1134-1139, 1998.

KLEIN D: Quantification using real-time PCR technology: applications and limitations. Trends Mol Med 8: 257-260, 2002.

LANDBO C, PRESCOTT E, LANGE P, VESTBO J, ALMDAL TP: Prognostic value of nutritional status in chronic obstructive pulmonary disease. Am J Respir Crit Care Med 160: 1856-1861, 1999.

LIU X, JI Y, CHEN J, LI S, LUO F: Circulating visfatin in chronic obstructive pulmonary disease. Nutrition 25: 373378, 2009.

MAGNI P, LIUZZI A, RUSCICA M, DOZIO E, FERRARIO S, BUSSI I, MINOCCI A, CASTAGNA A, MOTTA M, SAVIA G: Free and bound plasma leptin in normal weight and obese men and women: relationship with body composition, resting energy expenditure, insulin-sensitivity, lipid profile and macronutrient preference. Clin Endocrinol (Oxf) 62: 189-196, 2005.

MILLER MR, HANKINSON J, BRUSASCO V, BURGOS F, CASABURI R, COATES A, CRAPO R, ENRIGHT P, VAN DER GRINTEN CP, GUSTAFSSON P, JENSEN R, JOHNSON DC, MACINTYRE N, MCKAY R, NAVAJAS D, PEDERSEN OF, PELLEGRINO R, VIEGI G, WANGER J; ATS/ERS TASK FORCE: Standardisation of spirometry. Eur Respir J 26: 319-338, 2005.

MOTOSHIMA H, WU X, SINHA MK, HARDY VE, ROSATO EL, BARBOT DJ, ROSATO FE, GOLDSTEIN BJ: Differential regulation of adiponectin secretion from cultured human omental and subcutaneous adipocytes: effects of insulin and rosiglitazone. J Clin Endocrinol Metab 87: 5662-5667, 2002.

MURPHY RA, WILKE MS, PERRINE M, PAWLOWICZ M, MOURTZAKIS M, LIEFFERS JR, MANESHGAR M, BRUERA E, CLANDININ MT, BARACOS VE, MAZURAK VC: Loss of adipose tissue and plasma phospholipids: relationship to survival in advanced cancer patients. Clin Nutr 29: 482-487, 2010.

NEUHÄUSER-BERTHOLD M, HERBERT BM, LÜHRMANN PM, SÜLTEMEIER AA, BLUM WF, FREY J, HEBEBRAND J: Resting metabolic rate, body composition, and serum leptin concentrations in a free-living elderly population. Eur J Endocrinol 142: 486-492, 2000.

NHLBI/WHO GLOBAL INITIATIVE FOR CHRONIC OBSTRUCTIVE LUNG DISEASE (GOLD) WORKSHOP: Global strategy for the diagnosis, management, and prevention of chronic obstructive pulmonary disease. 2010 Update. Available from: $h t t p: / / w w w . g o l d c o p d . c o m$

NISKANEN L, HAFFNER S, KARHUNEN LJ, TURPEINEN AK, MIETTINEN H, UUSITUPA MI: Serum leptin in relation to resting energy expenditure and fuel metabolism in obese subjects. Int J Obes Relat Metab Disord 21: 309-313, 1997.

PANNACCIULLI N, VETTOR R, MILAN G, GRANZOTTO M, CATUCCI A, FEDERSPIL G, DE GIACOMO P, GIORGINO R, DE PERGOLA G: Anorexia nervosa is characterized by increased adiponectin plasma levels and reduced nonoxidative glucose metabolism. J Clin Endocrinol Metab 88: 1748-1752, 2003.

PELLEYMOUNTER MA, CULLEN MJ, BAKER MB, HECHT R, WINTERS D, BOONE T, COLLINS F: Effects of the obese gene product on body weight regulation in ob/ob mice. Science 269: 540-543, 1995.

RAGUSO CA, LUTHY C: Nutritional status in chronic obstructive pulmonary disease: role of hypoxia. Nutrition 27: 138-143, 2011.

SCHOLS AM, FREDRIX EW, SOETERS PB, WESTERTERP KR, WOUTERS EF: Resting energy expenditure in patients with chronic obstructive pulmonary disease. Am J Clin Nutr 54: 983-987, 1991a.

SCHOLS AM, SOETERS PB, MOSTERT R, SARIS WH, WOUTERS EF: Energy balance in chronic obstructive pulmonary disease. Am Rev Respir Dis 143: 1248-1252, $1991 \mathrm{~b}$.

SCHOLS AM, CREUTZBERG EC, BUURMAN WA, CAMPFIELD LA, SARIS WH, WOUTERS EF: Plasma leptin is related to proinflammatory status and dietary intake in patients with chronic obstructive pulmonary disease. Am J Respir Crit Care Med 160: 1220-1226, 1999. 
SERGI G, COIN A, MARIN S, VIANELlO A, MANZAN A, PERUZZA S, INELMEN EM, BUSETTO L, MULONE S, ENZI G: Body composition and resting energy expenditure in elderly male patients with chronic obstructive pulmonary disease. Respir Med 100: 1918-1924, 2006.

SHIN KC, CHUNG JH, LEE KH: Effects of TNF-alpha and leptin on weight loss in patients with stable chronic obstructive pulmonary disease. Korean J Intern Med 22: 249-255, 2007.

SMIECHOWSKA J, UTECH A, TAFFET G, HAYES T, MARCELLI M, GARCIA JM: Adipokines in patients with cancer anorexia and cachexia. J Investig Med 58: 554-559, 2010.

TOMODA K, YOSHIKAWA M, ITOH T, TAMAKI S, FUKUOKA A, KOMEDA K, KIMURA H: Elevated circulating plasma adiponectin in underweight patients with COPD. Chest 132: 135-140, 2007.

TRAYHURN P, BING C: Appetite and energy balance signals from adipocytes. Philos Trans R Soc Lond B Biol Sci 361: 1237-1249, 2006.

USUI C, TAKAHASHI E, GANDO Y, SANADA K, OKA J, MIYACHI M, TABATA I, HIGUCHI M: Relationship between blood adipocytokines and resting energy expenditure in young and elderly women. $J$ Nutr Sci Vitaminol (Tokyo) 53: 529-535, 2007.

VESTBO J, PRESCOTT E, ALMDAL T, DAHL M, NORDESTGAARD BG, ANDERSEN T, SØRENSEN TI, LANGE P: Body mass, fat-free body mass, and prognosis in patients with chronic obstructive pulmonary disease from a random population sample: findings from the Copenhagen City Heart Study. Am J Respir Crit Care Med 173: 79-83, 2006.

WAGNER PD: Possible mechanisms underlying the development of cachexia in COPD. Eur Respir J 31: 492-501, 2008.

WEIR JB: New methods for calculating metabolic rate with special reference to protein metabolism. J Physiol 109: 1-9, 1949.

WOLF I, SADETZKI S, KANETY H, KUNDEL Y, PARIENTE C, EPSTEIN N, OBERMAN B, CATANE R, KAUFMAN B, SHIMON I: Adiponectin, ghrelin, and leptin in cancer cachexia in breast and colon cancer patients. Cancer 106: 966-973, 2006.

YANG YM, SUN TY, LIU XM: The role of serum leptin and tumor necrosis factor-alpha in malnutrition of male chronic obstructive pulmonary disease patients. Chin Med J (Engl) 119: 628-633, 2006. 